\title{
むかばぎんあんさらトくろはざんあんさらトノ 胞子栥生二就イテ
}

\author{
㺘野俊本
}

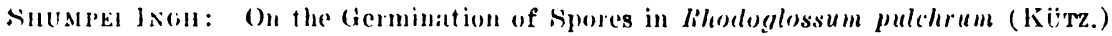

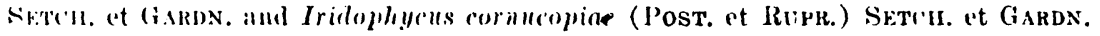

Reccivid becimber $18,1940$.

\section{緒咅}

あかばぎんあんさう(文八うすばざんあんさう)纸くろはさんあんさう(メ八あつ

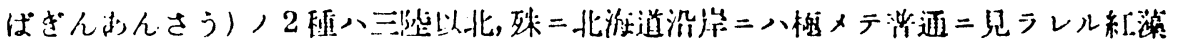

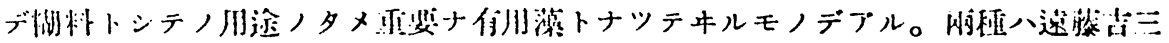

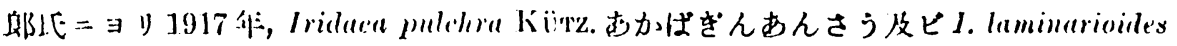

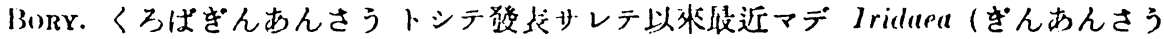

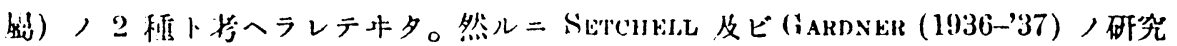

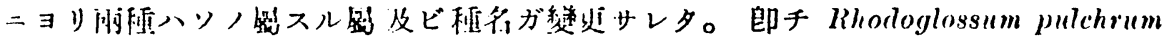

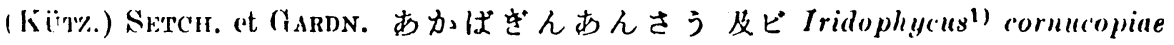

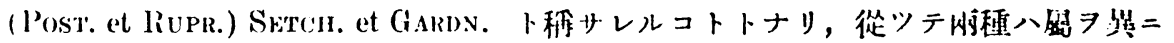

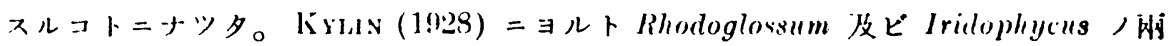

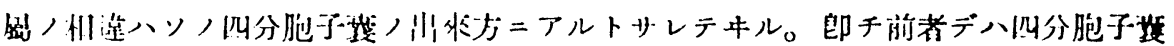

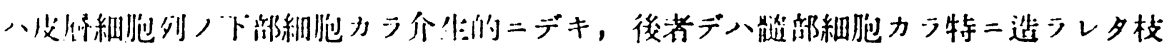

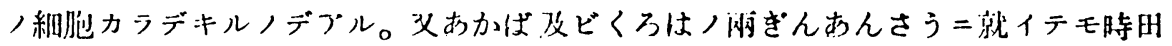

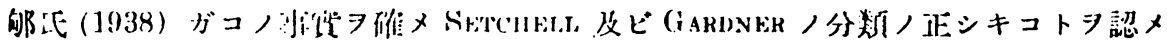
テキル。

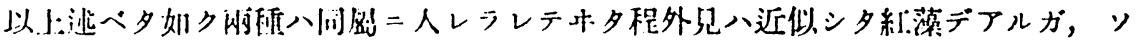

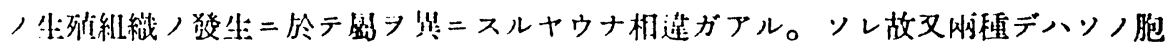

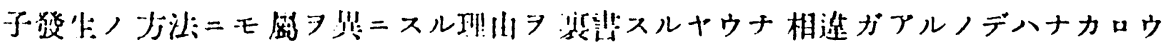

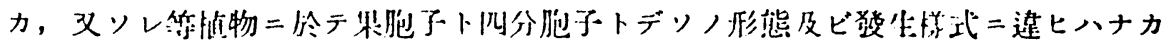

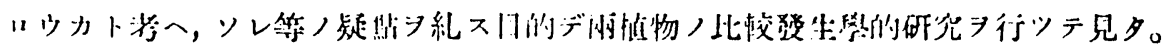

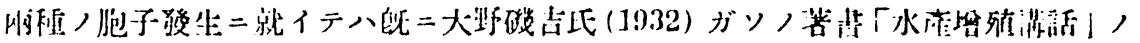

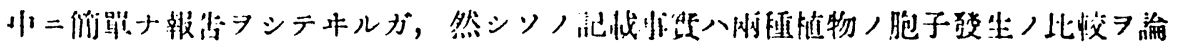

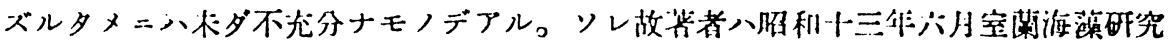

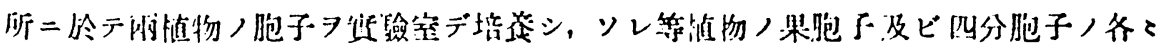

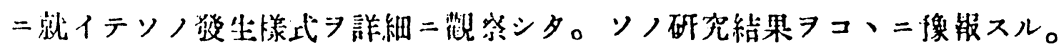

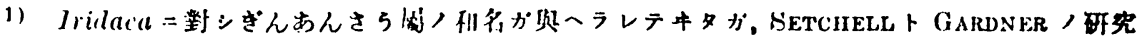

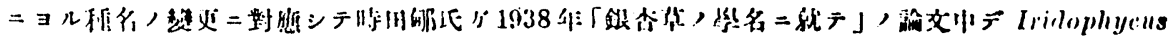

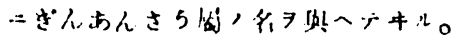




\section{材料 卜方法}

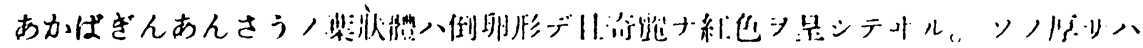

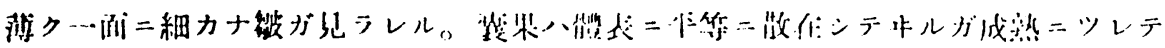

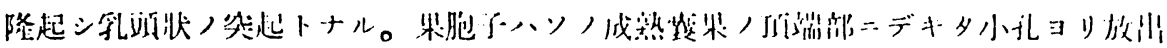

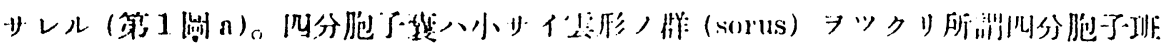

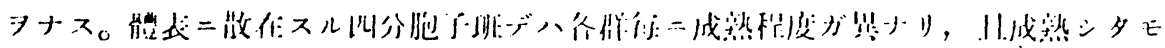

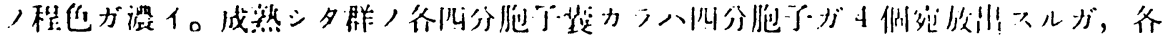

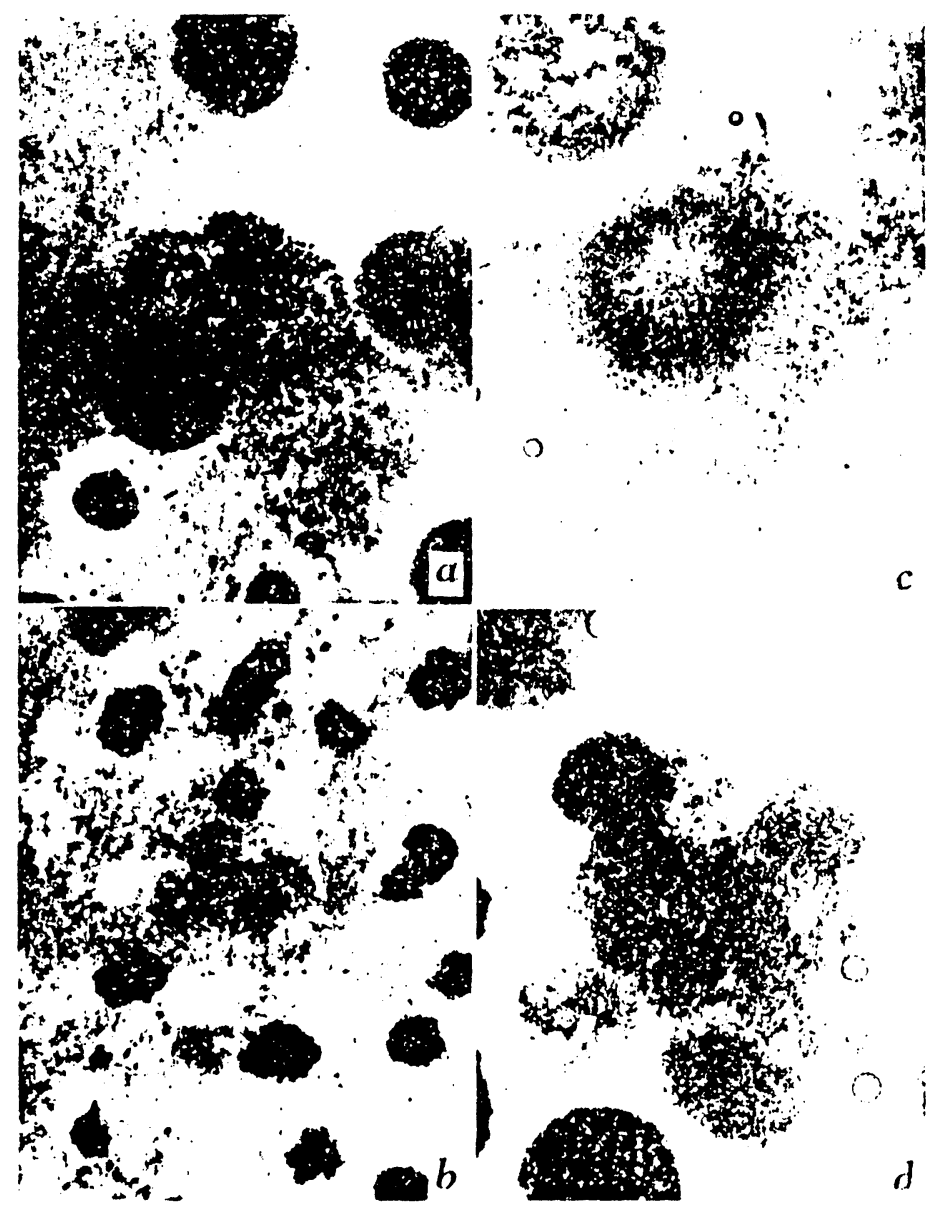

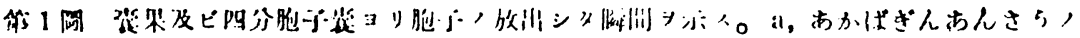

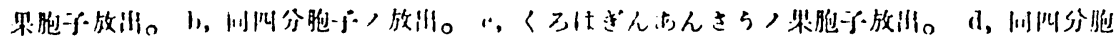

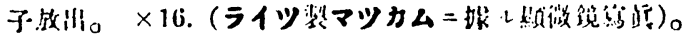

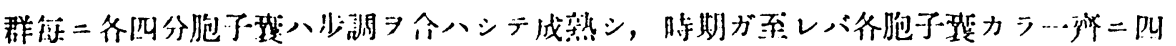

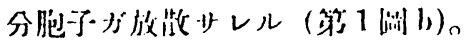

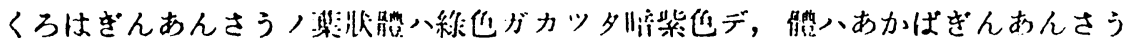




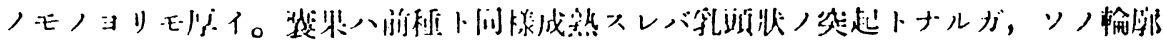

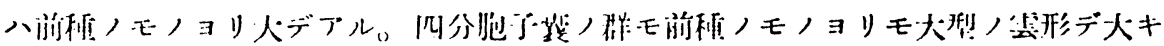

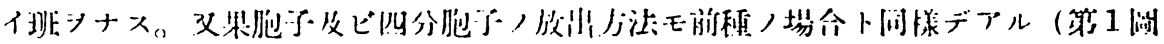
c, d)。

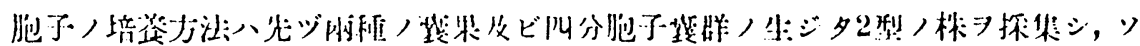

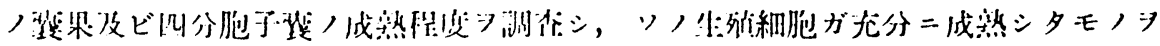

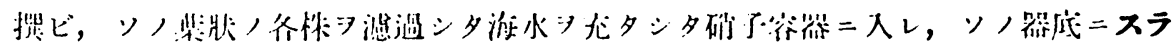

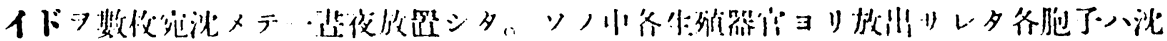

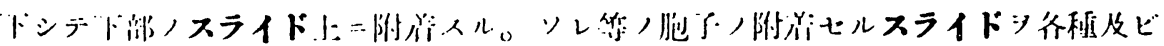
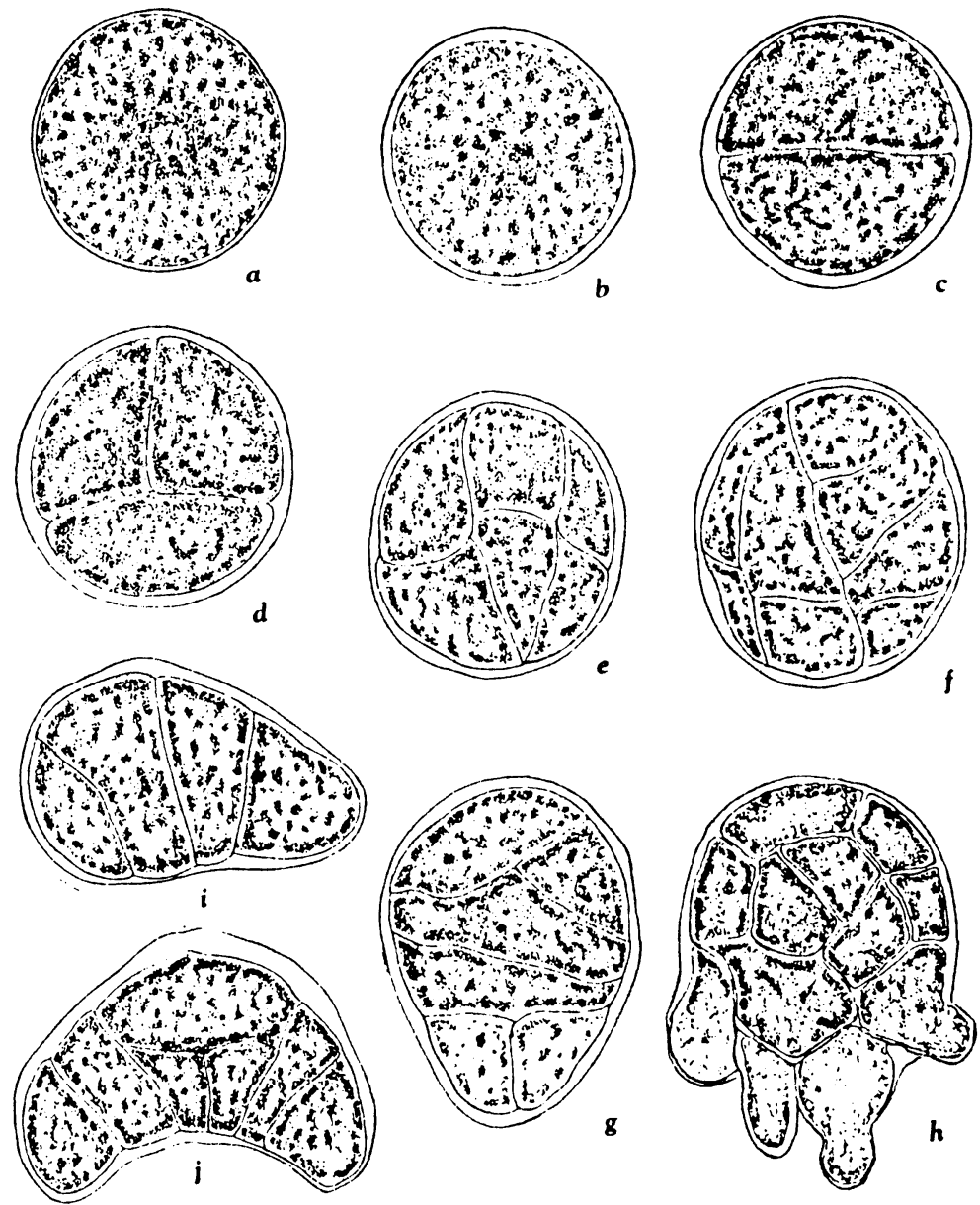

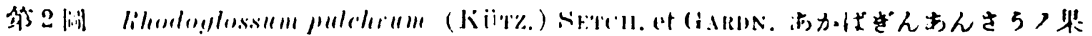

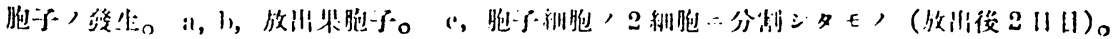

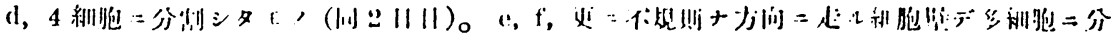
則:

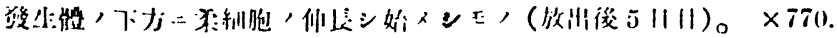




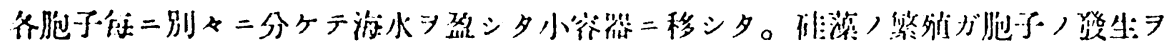

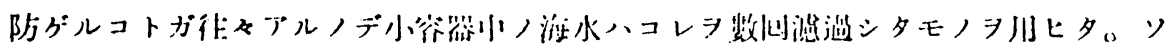

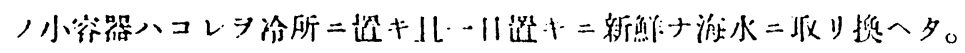

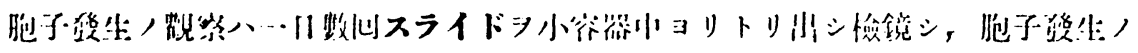

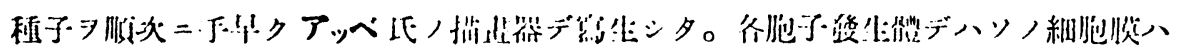

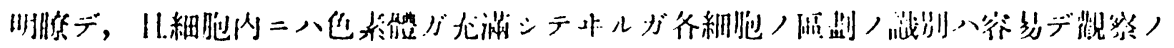

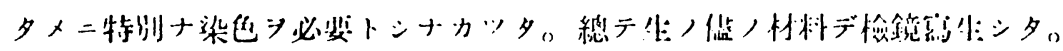

\section{觀察}

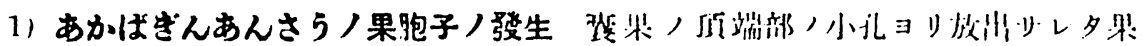

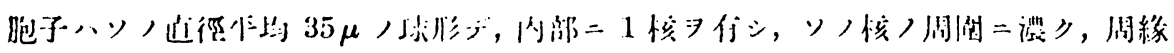

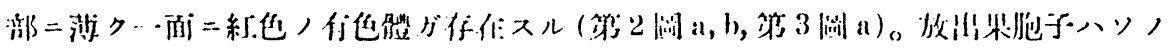
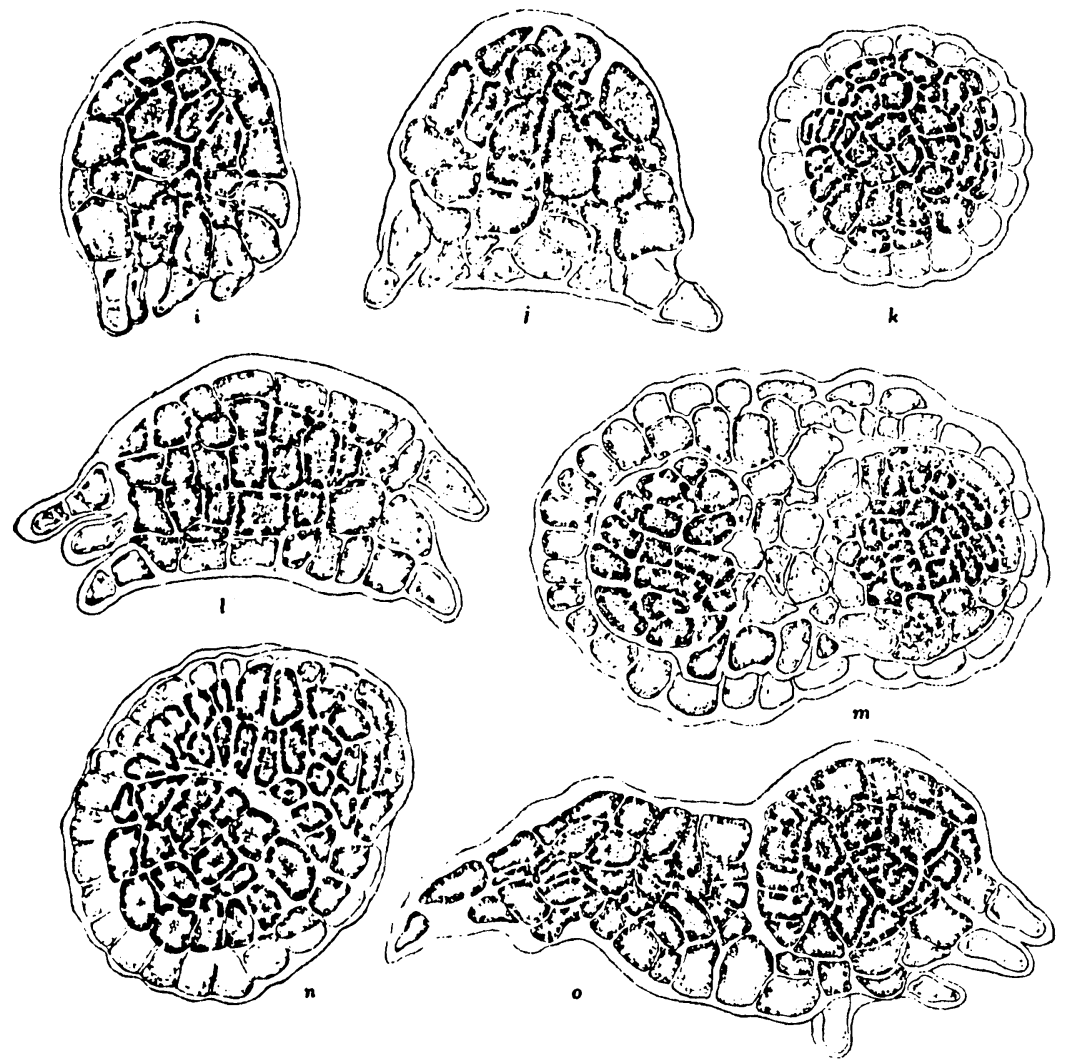

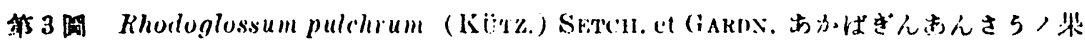

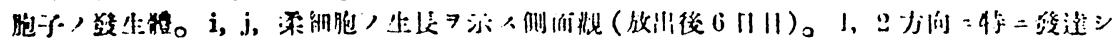

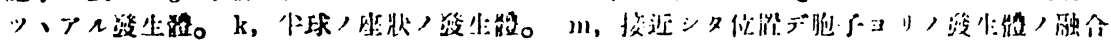

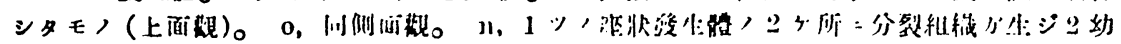
茅二相シッ、アルモノ。 


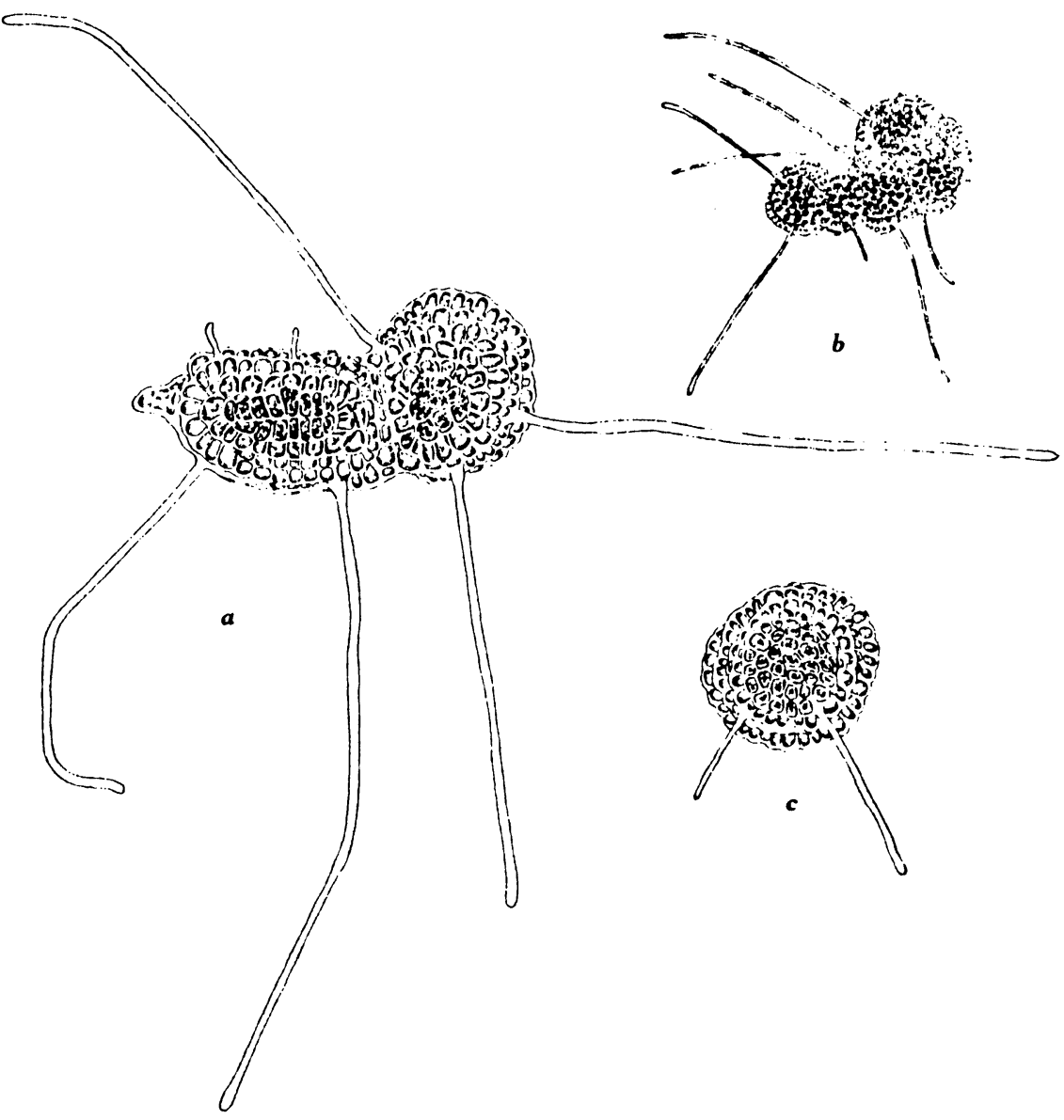

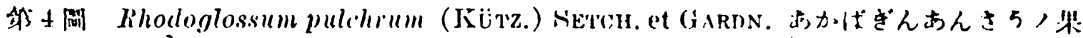

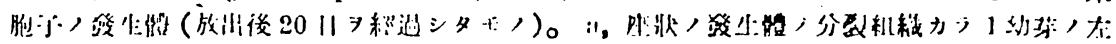

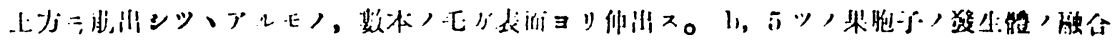

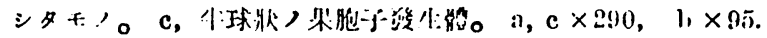

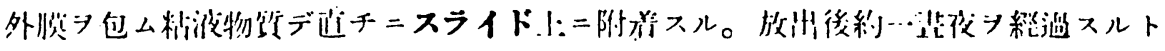

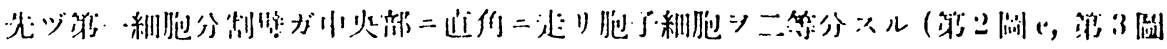

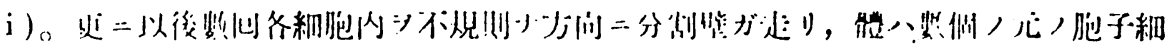

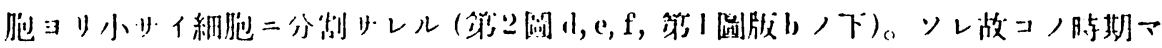

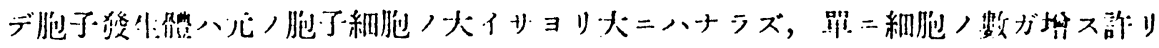

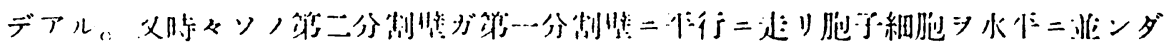

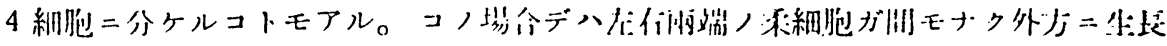

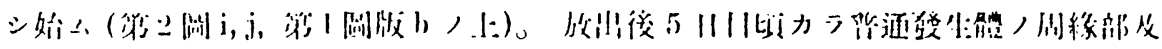

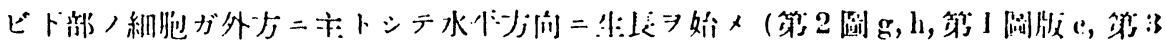

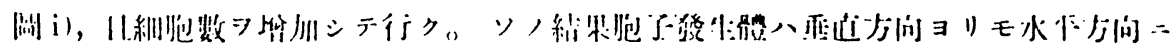




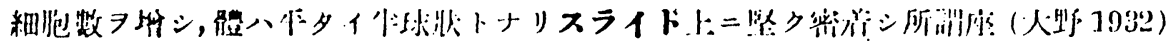

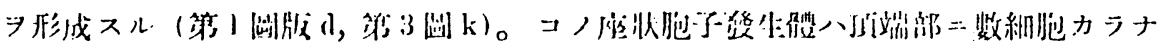

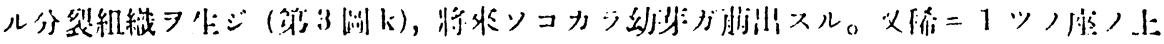

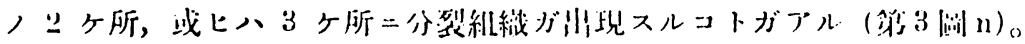
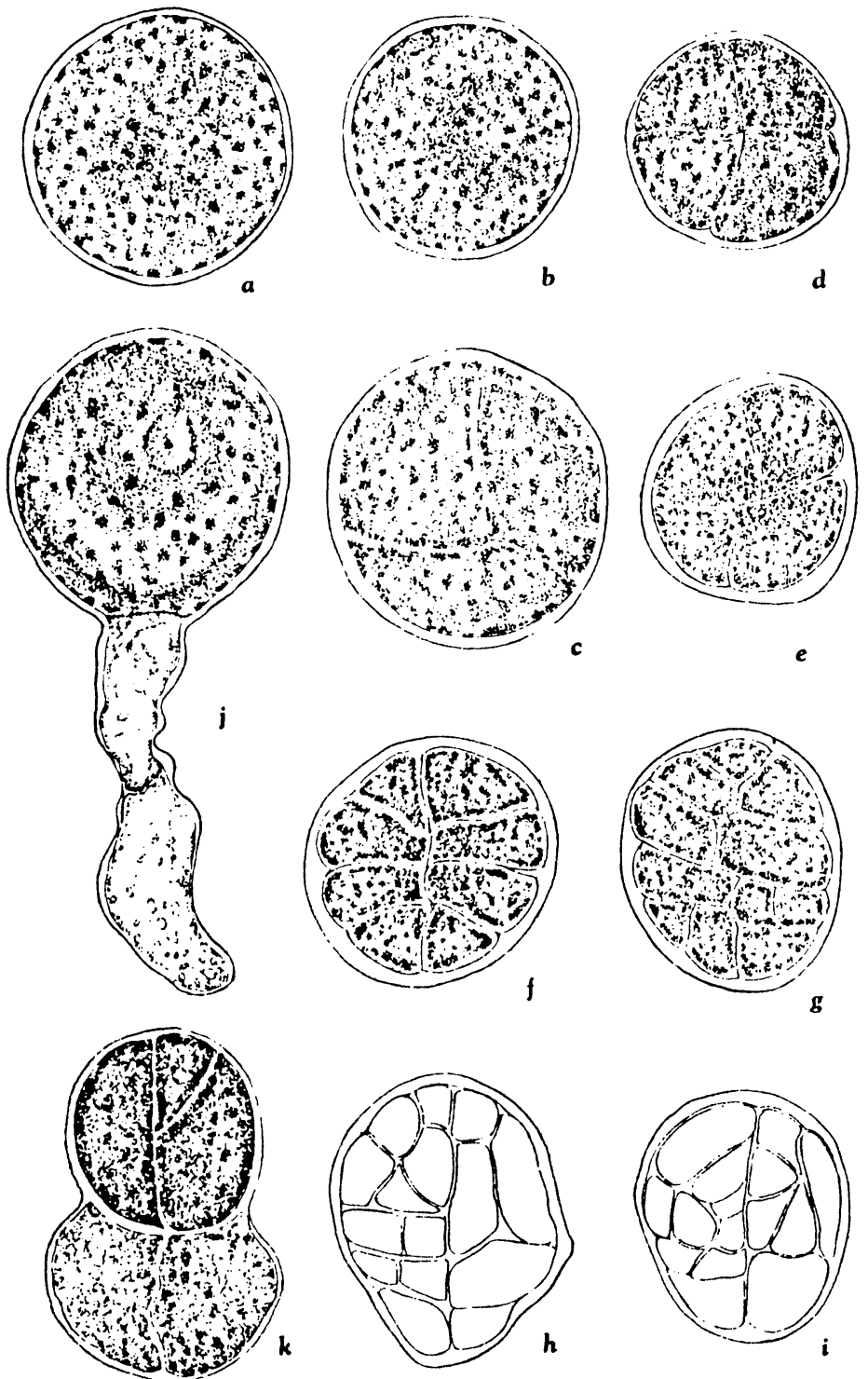

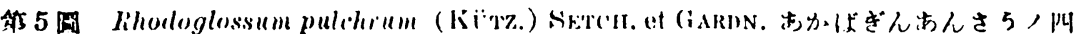

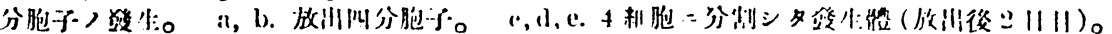

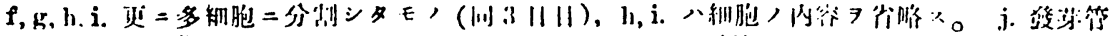

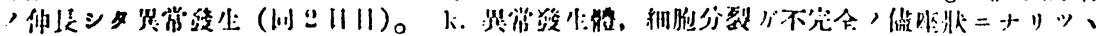

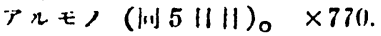




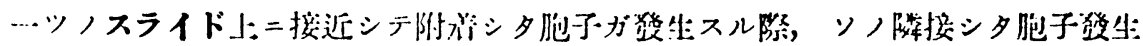

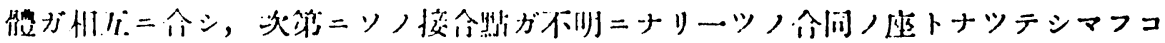

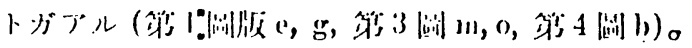

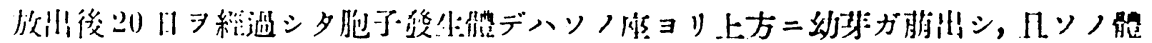
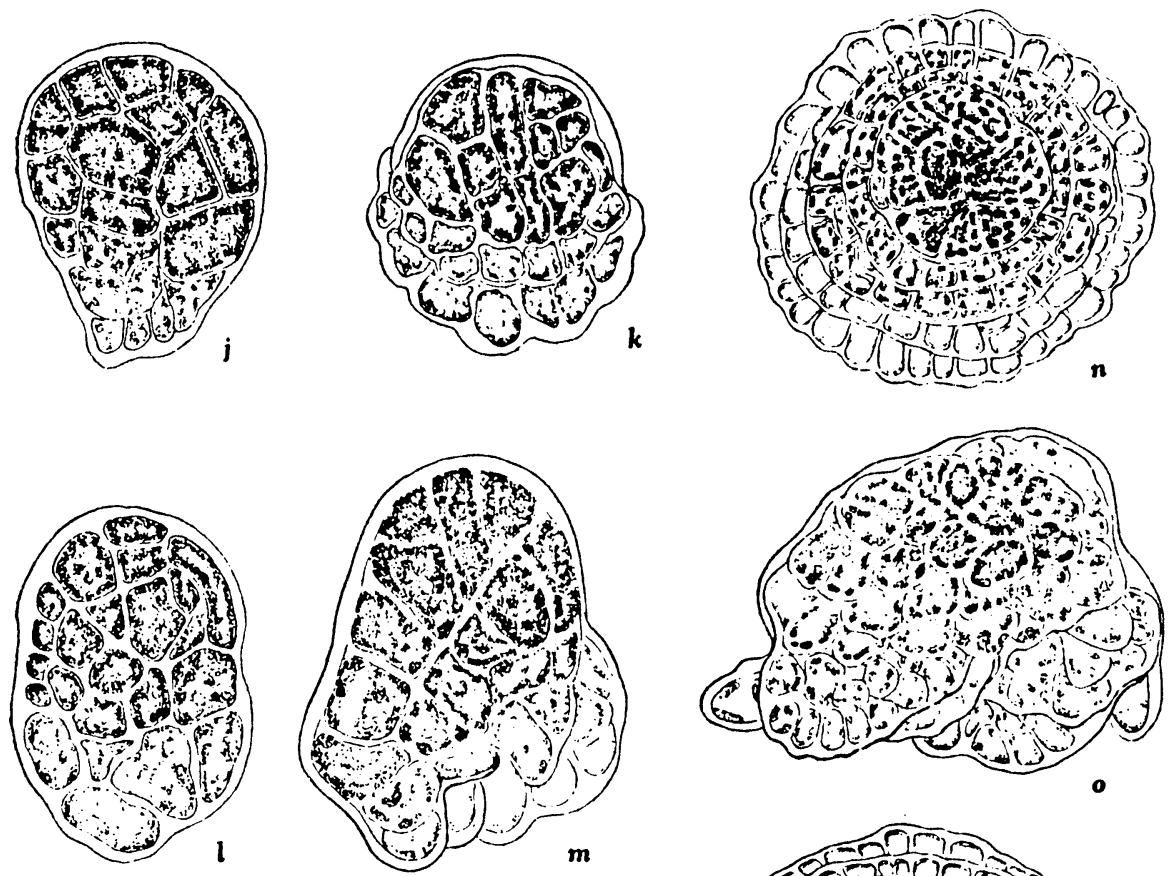

m

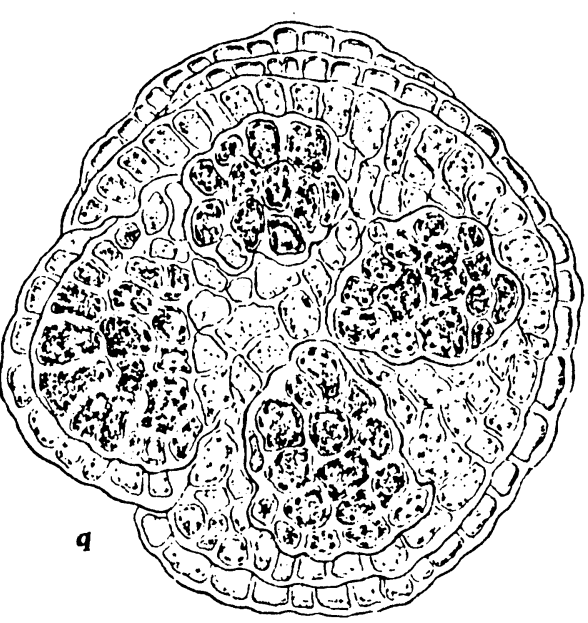

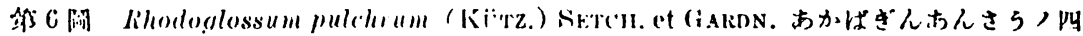
分肥于

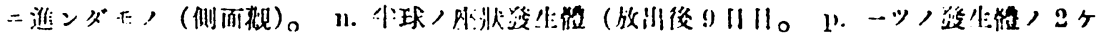

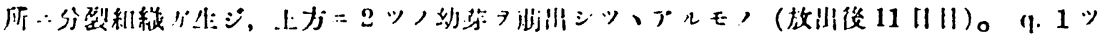

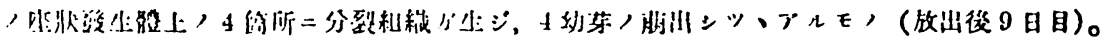
$\times 770$. 


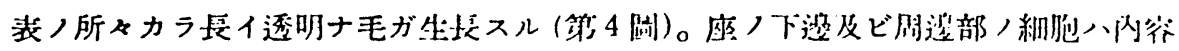

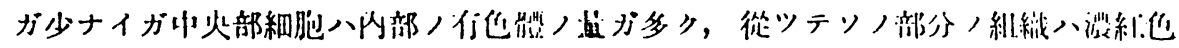
习呈シテキル。

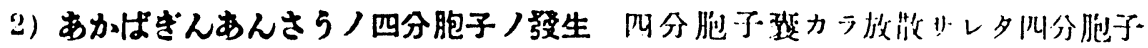

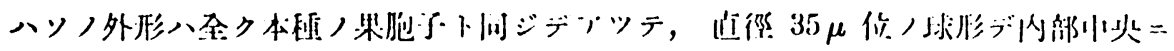

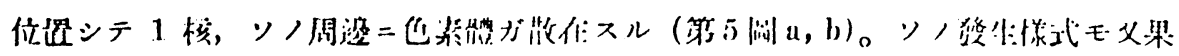

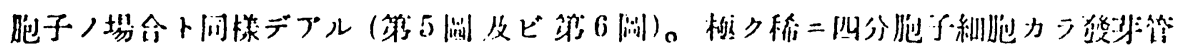

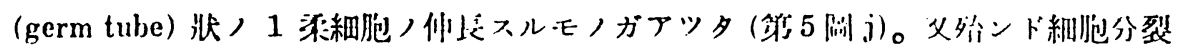

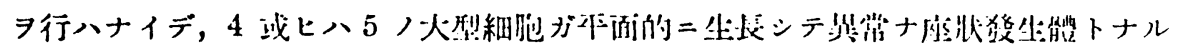

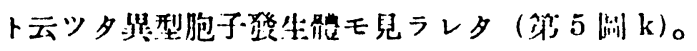

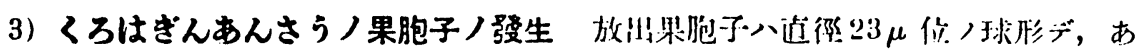

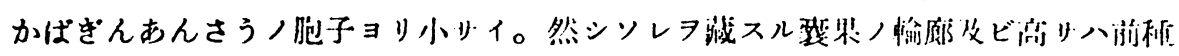
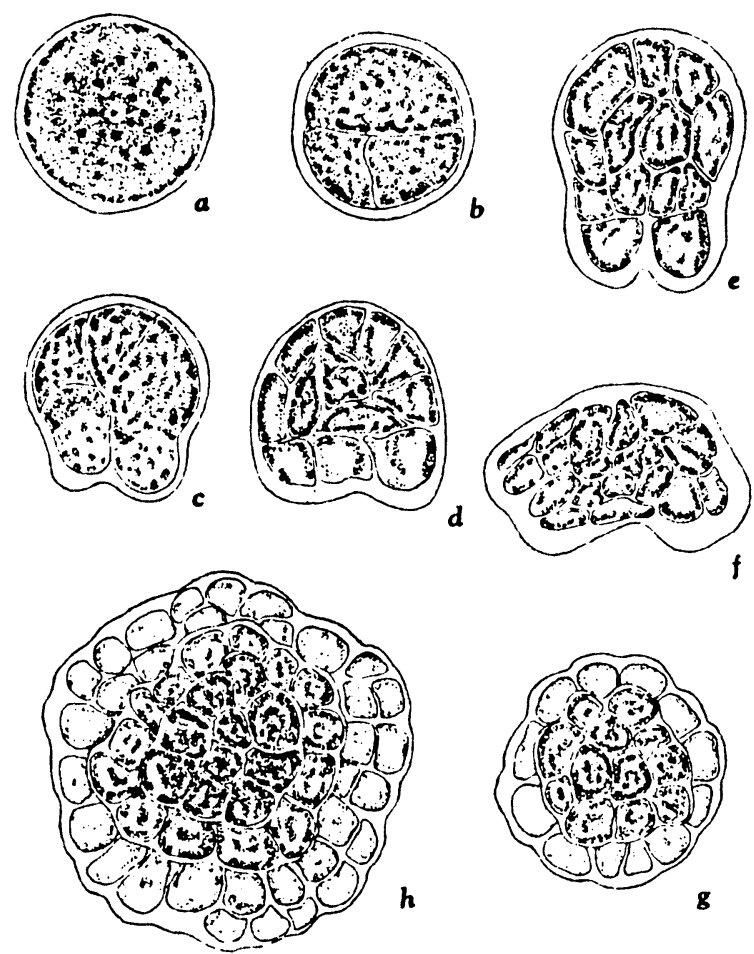

等 7 Iridophycus cornucopiar (['os't. et Rupk.)

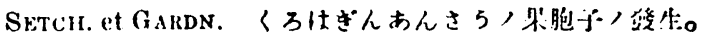

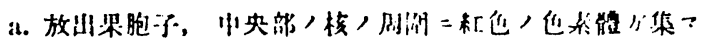

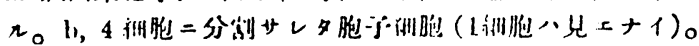

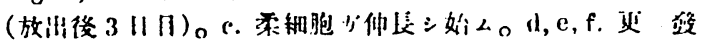

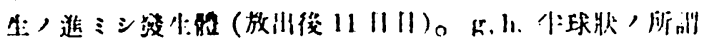

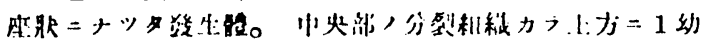

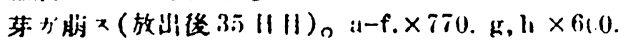

ノモノョリ大デてルカラ 1

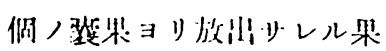

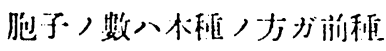
ノモノョリ多イ(第; 1 阔| c)。

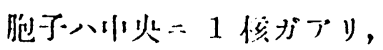

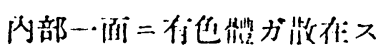

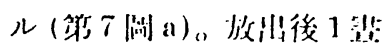
位ノ後二八胞子一細胞八川尖

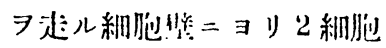
ニ分别リレ，ソレ二緢イテ 程々ナ方问二这儿第二以徭

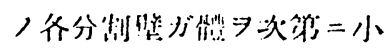
サイ細此二分测、儿。後ト

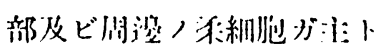

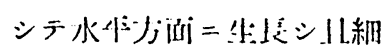

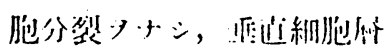

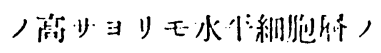

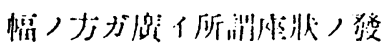

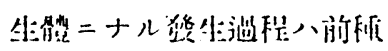
ノモノ卜人䧄㤖ジデテル (第; 7 洲)。

4)くろはきんあんさう ノ四分胞子ノ發生 川分胞

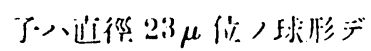

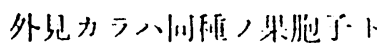

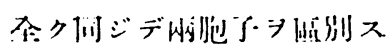


ルコトハデキナイ(第8圆a)。 又胞子镂生ノ方沙モ果胞子， モノト大踥间ジデアル(第8䧕 $d, e, f, g, h, i, j, k)$ 。堡 $\varepsilon$ 四分 胞于・カラ路雅篗 (germ tube) 狀ノ来細胞ノ突出 7 胃ルコト ガアル(第洞b,c)。然シコノ 突出深細犯八二三八細胞二分 制サレルノミデッレ以上八生 恬シナイ。ソレニ仪シ胞子細

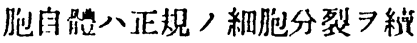
ケテ盤状ノ墢生能トナルガン

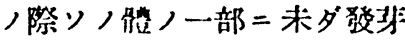
管狀ノ細胞ガ殘ツテキル；

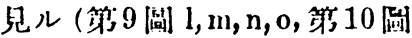
b)。文時 $=2$ 以上，㷋非管状 ノ突起习見ルコトガアル(第9

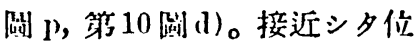
谓ニアル幾ツカノ胞子發生娟 ガ命着シ，ソノ境界ガ不明卜 ナリ介间ノ座ヨ形成スルコト ノ兄ラレルコトハ能程ノ埸合 ト闬ジデアル(第10阔e)。

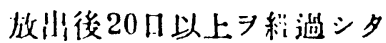
胞子發尘赫八同心四的排列 ナース多クノ細肥底カラナル回 形ノ所謂座 $习$ 形成シテキル

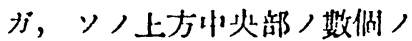
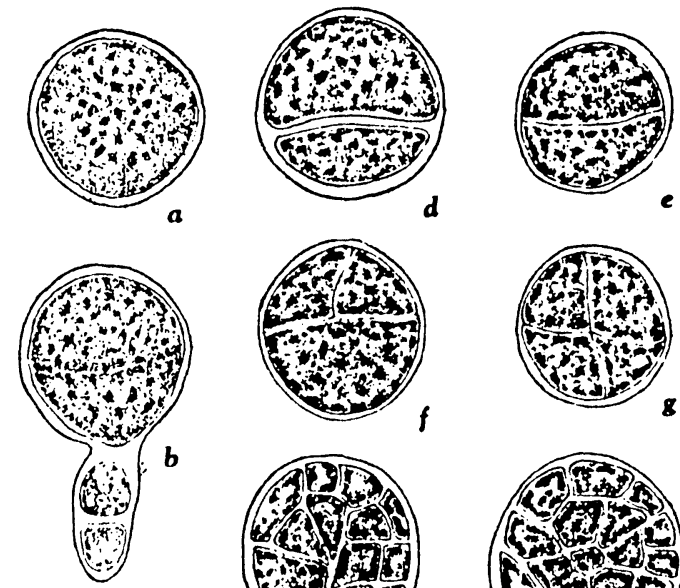

$f$
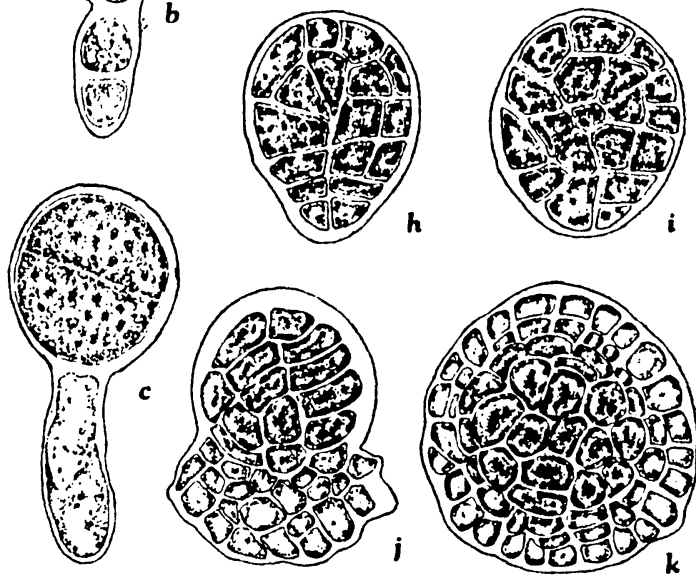

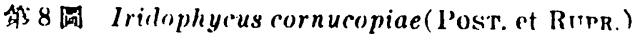

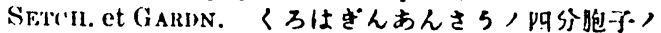

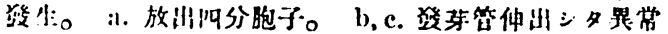

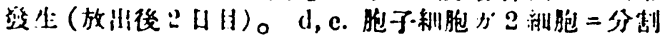
サル(2 III )。 f,g. 4 湅胞二ナツタ發生

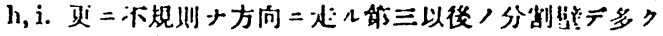

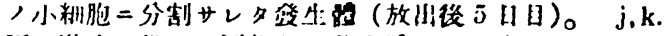

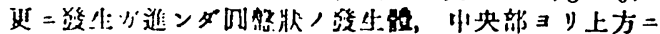

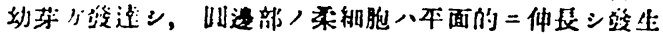

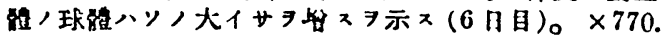

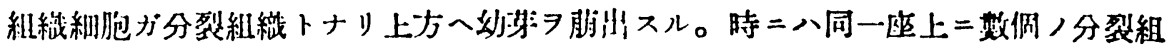

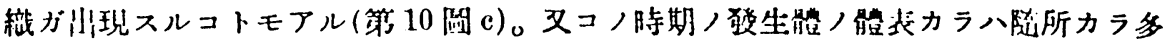

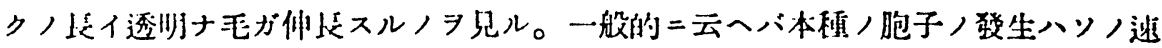

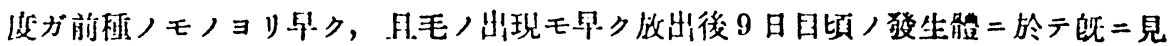
テレタ。

\section{考 察 1哧 锅}

あかばざんあんさう及どくろはさんあんさうノ胞子破生ハ先ヅ胞子細胞自能 / 細

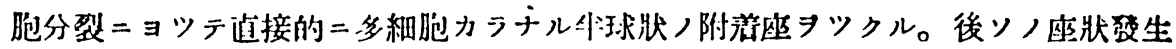

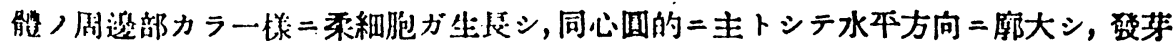



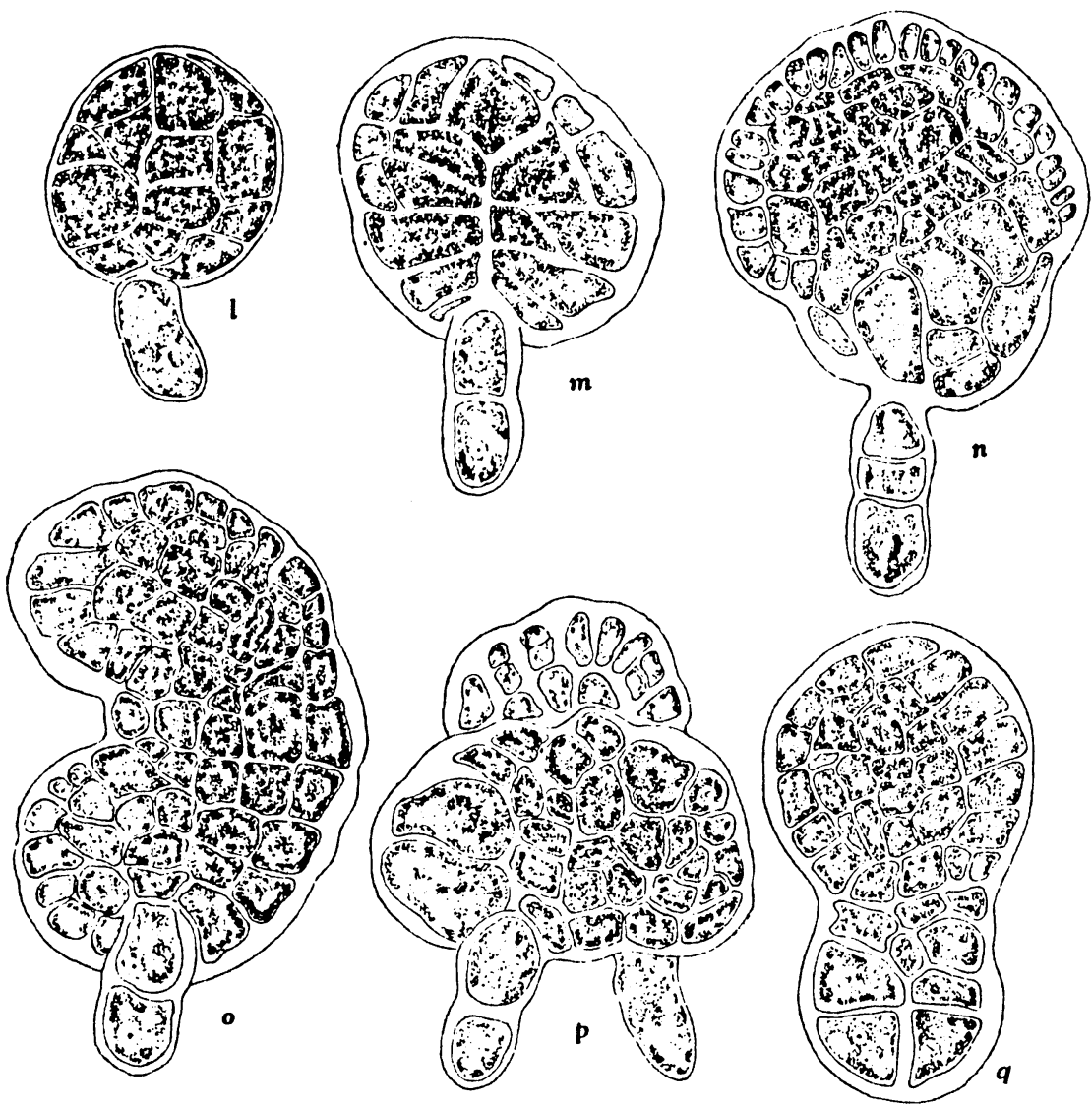

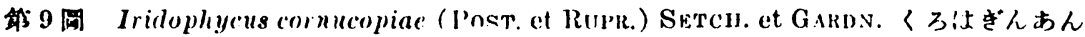

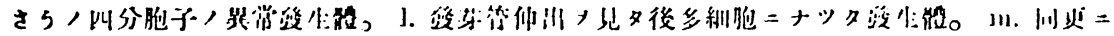

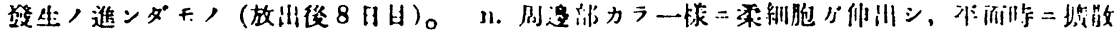

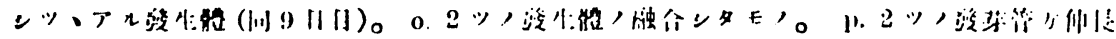

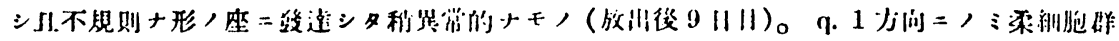

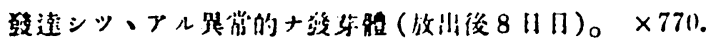

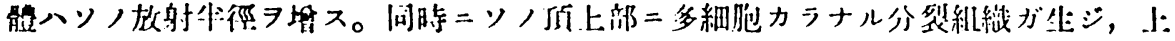

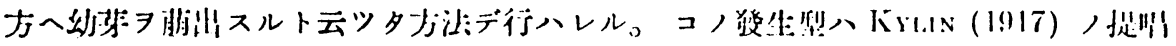

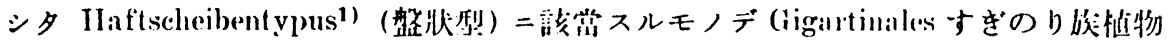

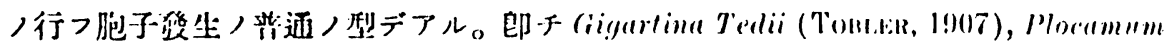

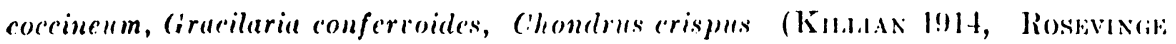
1931), Cystoclonium purpurascens. (K ysan 1917), Mh!llophora Brodiaci, Ahnselliu

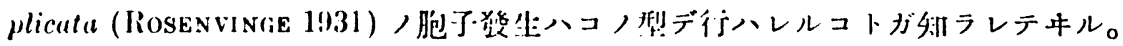

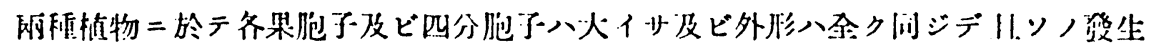

1) KYin (1917) ガ OLtmanss

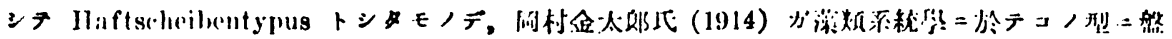
犾型卜云フ名程 7 舆一夕。 

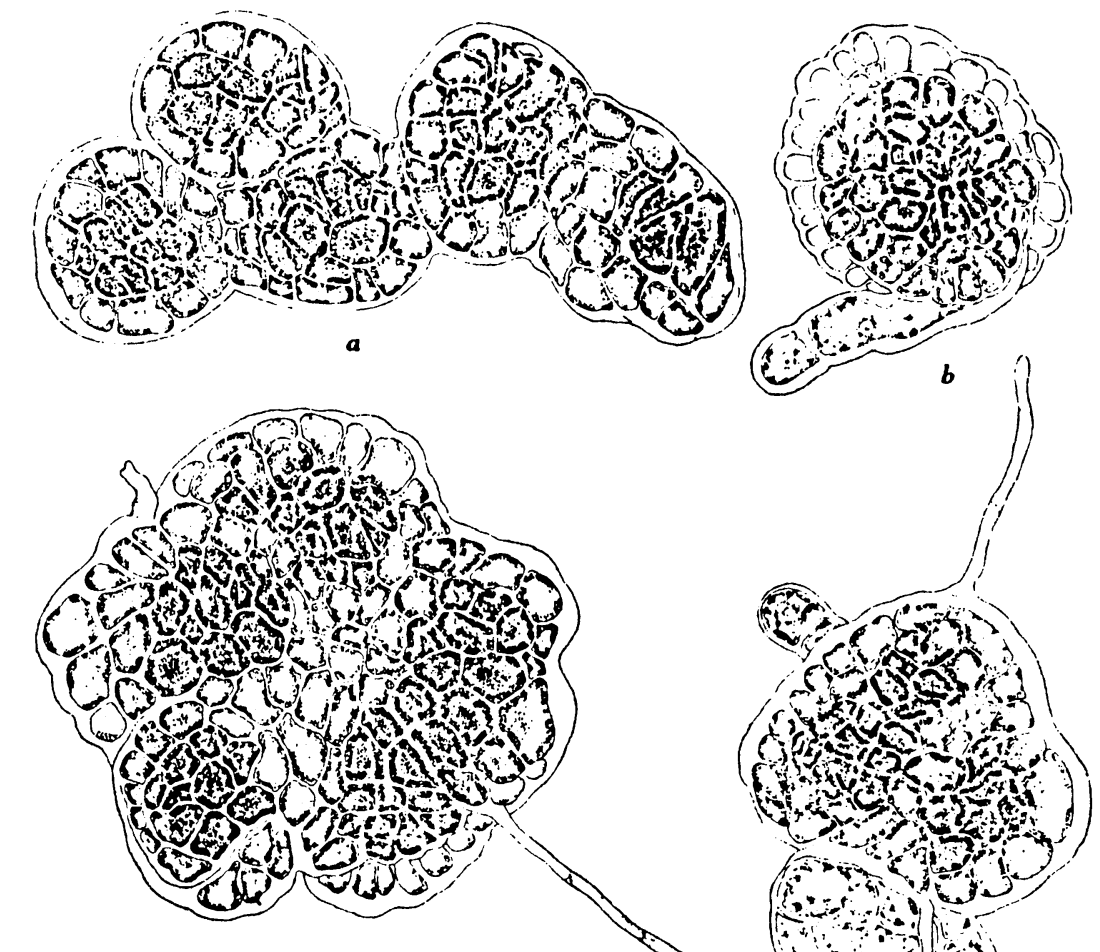

c
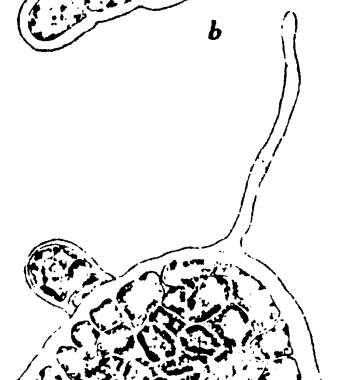

s.
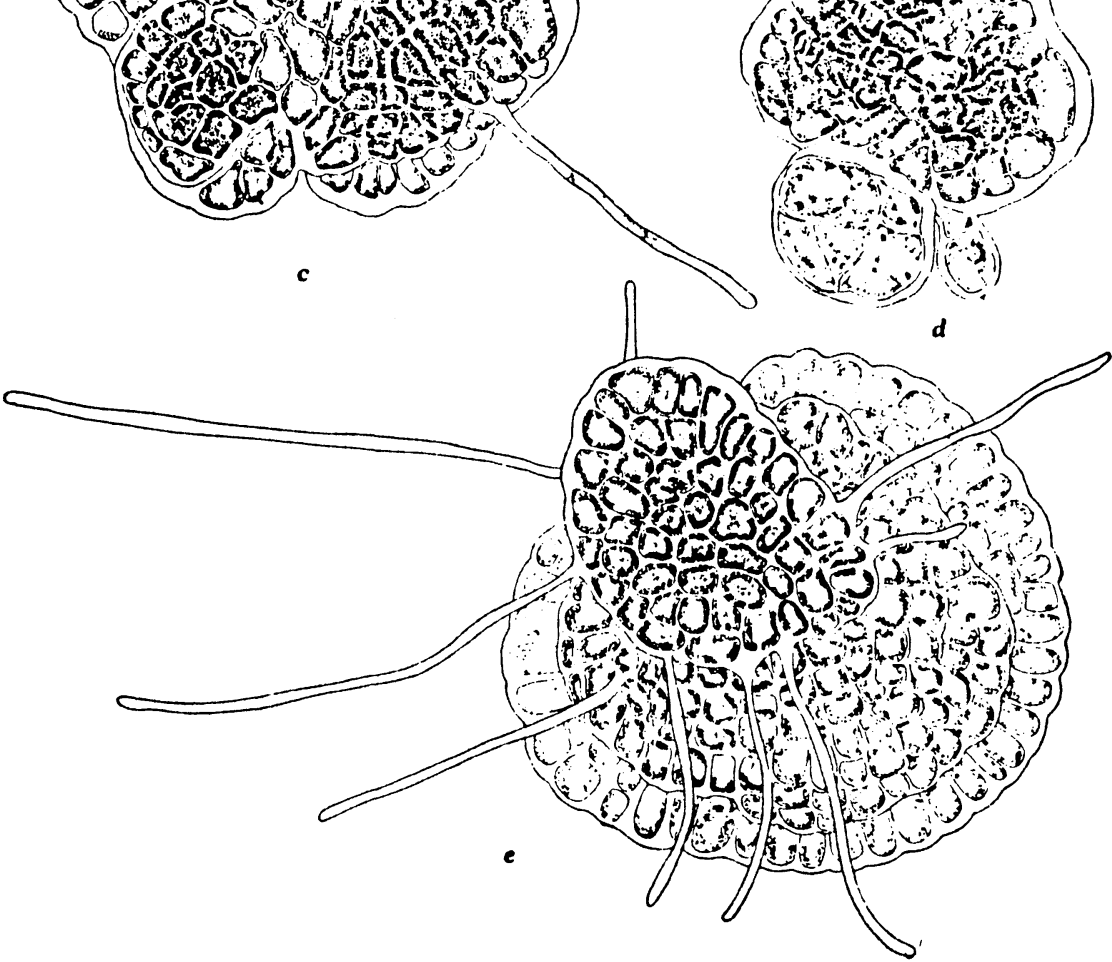

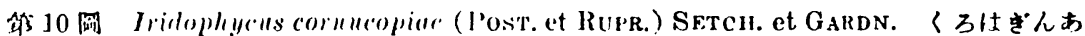

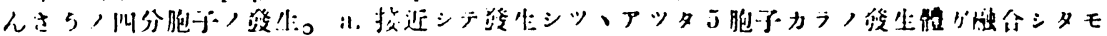

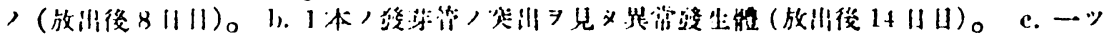

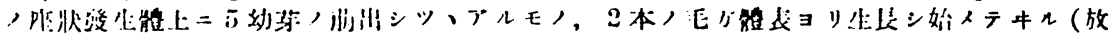

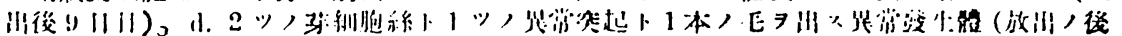

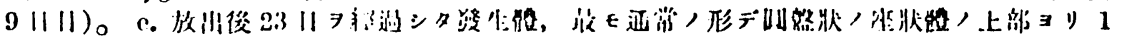

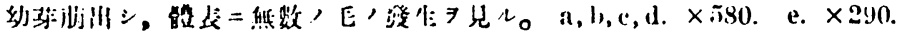



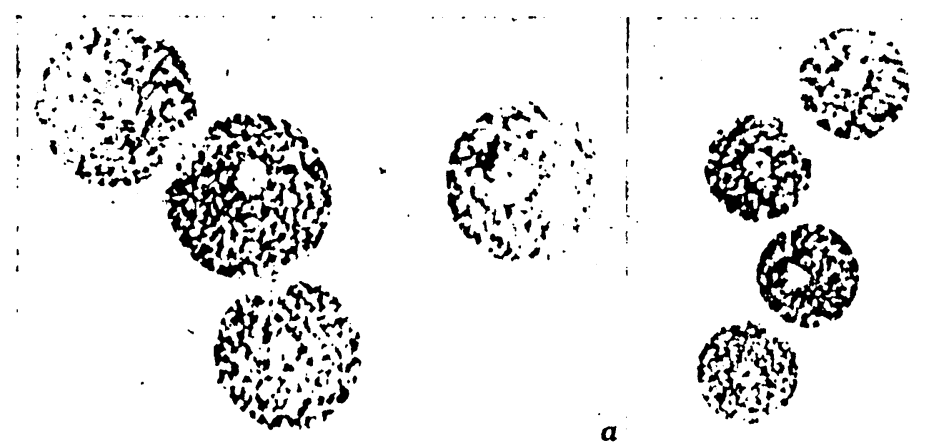

$a$

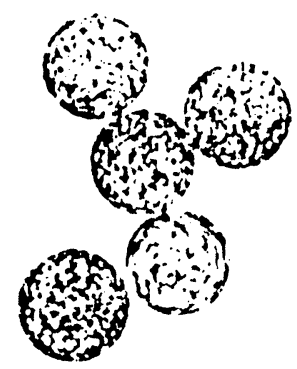

b

$d$

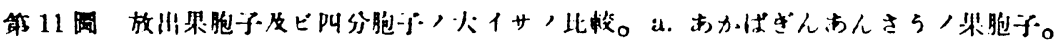

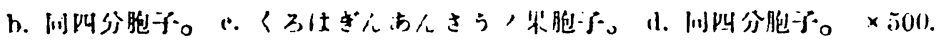

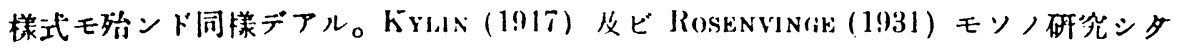

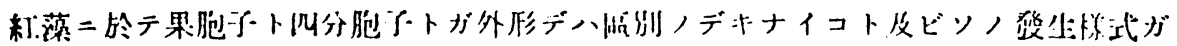

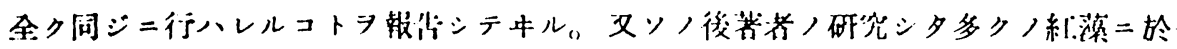

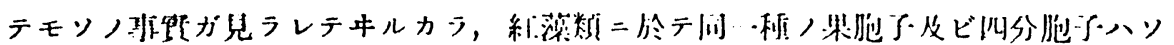

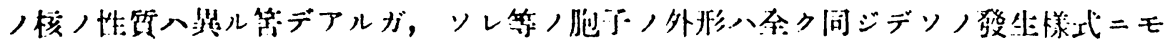
厓罗ハナイモノデアル。

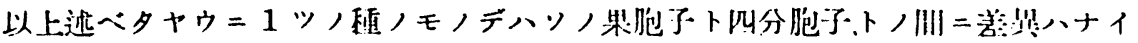

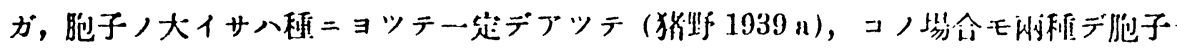

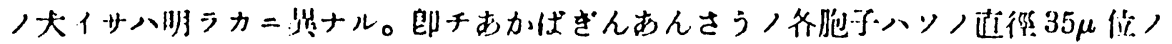

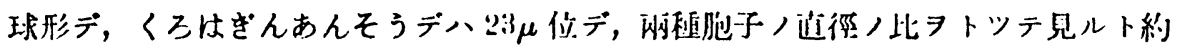
$2: 3$ ニナル位/差ガアル(第 11 附)。

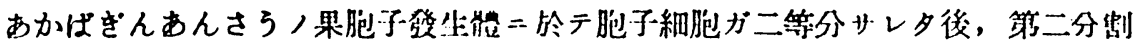

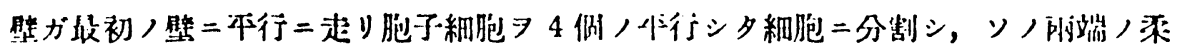

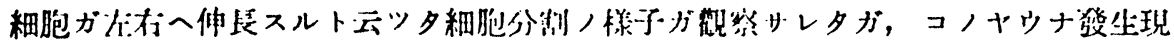

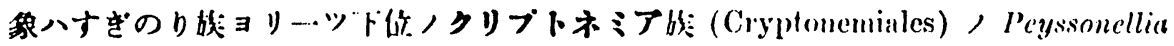

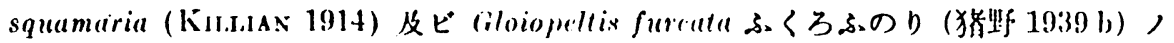

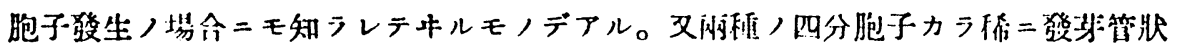

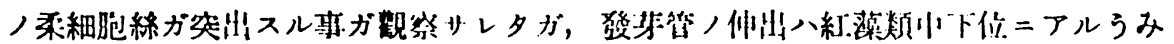


ぞうめ九族 (Nemalionales) 及ビクリブトネミア施 (Cryptonemiales) / Grateloupia,

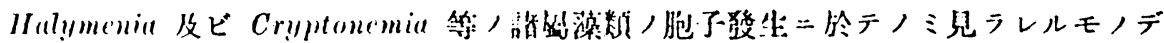

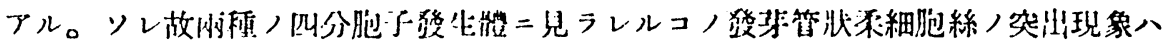

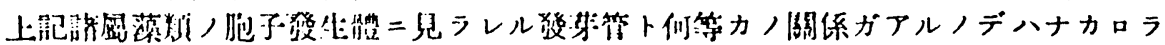

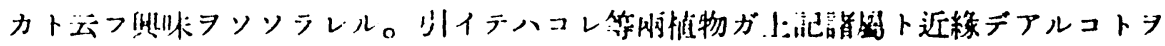
㟝示シティルノデハナカロウカト慙ハレル。

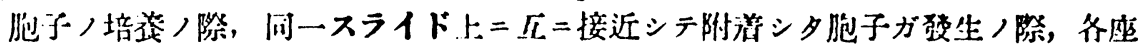

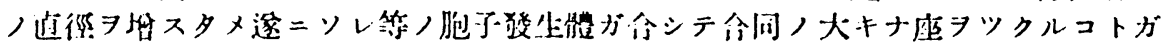

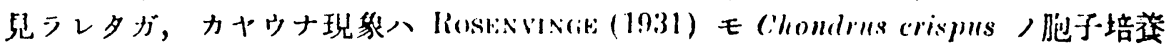

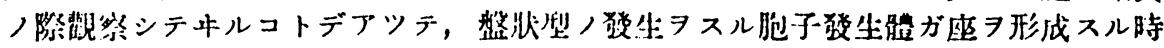
期二ヨク起儿利挝ノヤウデフル。

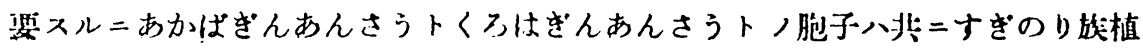

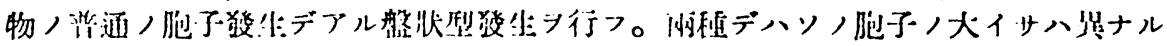

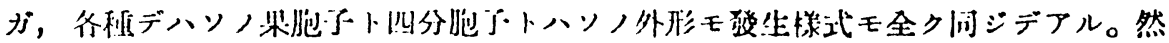
シ胞子細胞ノ小サイくろはざんあんさうノオガあかばざんあんさうノモノョリンノ

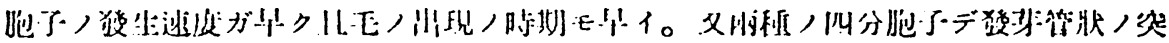

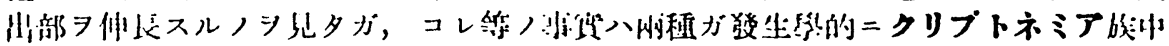

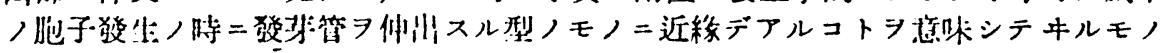
デハナカロウカト将へル。

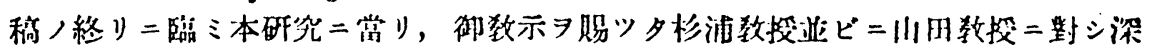

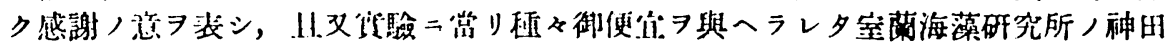

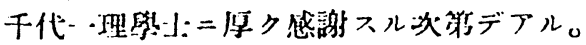

\section{Résumé.}

In the present paper the gremination of carpospores and tetraspores

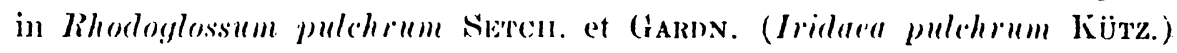

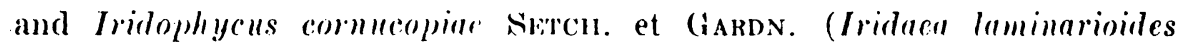
Bony) is dealt with. 'J'he carpospores and tetraspores present the same size and form within each species, but the size of the spores of these two species is different, the diameter of the former being 35 " and the latter $23 \mu$. The mammer of development of the spores was formd to be the same in the two speries. The spore-cell, withont change in size, is first divided into two by lorming a perpendicular wall, and further by forming rather irregularly orientated walls it develops to a certain number of eells. After this stage the germling forms ustually a cleeply red hemispherical dise with a fairly regular ontline, then increases in vertical ralius by the marginal growth and subseruently becomes a more flat and expanded dise. Thus in these species the germ dises arise always by direct segmentations of their spore-cells. In gremlings of about 20 days old, the first upright shoot develops from the meristem of the upper part of body and many long hyaline hairs spring from the surface of the boty. Generally speaking, the germination of the spores in the present two species always takes place in the mamner known as the disc-type (IIaftscheibentypus" 
Kron 1917) which is rommonly fomml in (iigartimales, and the smaller spores in I. cormencopiue develops earlier than the larger ones in $R$. pulchrum and also the hyaline hairs appear on the surface of the germoling of the former in a more early stage than the latter.

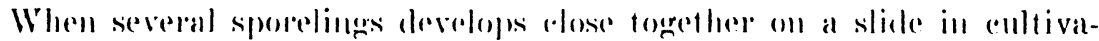
tion, they often fuse together into a large disc-body withont any distinct limit between them.

In I. cormucopine it was frespently fomm that parenchymatons filaments resembling in appearame to the germ-tubes protrule from the tetraspore-cell, while in $R$. pulchrum this is rather rarely met with. It will be interesting to note that the formation of such filaments in these sprecies seems to he related with the grem-tube formation known in some

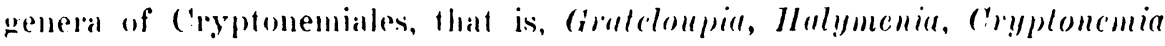
etc.

\section{引用文 獻}

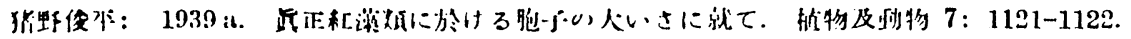

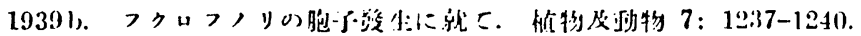

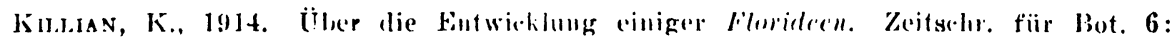
209-27\%.

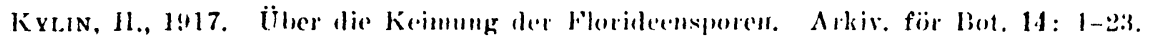

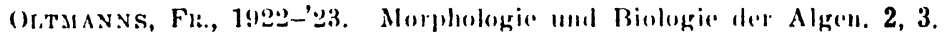

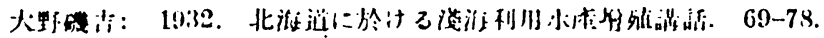

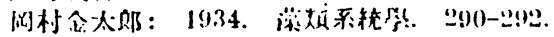

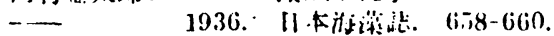

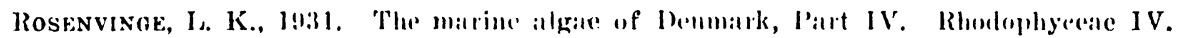
(Gigartinales, Rhorlymmiales, Nemastomaless).

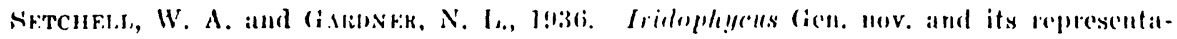
tion in South Ameriea. Proc. Nat. Aratl. Se. 22(8): $469+\ldots+33$.

1937. Trielephyeus in the Northern Hemispluere. Proce. Nat. Acall. Se. 23(3): 1i!) -174 .

1937. Iridephyeus with spereial reforemere to the Sonth American spereies. Univ. ('alif. Pull. I3ut., 19 (6) : 19.7-244.

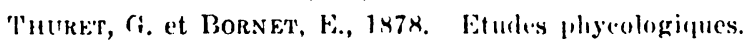

T'orl.kr, Fr., 1903. Bentrïge zur bitwirklungsgeschichte und Biologie einiger Mecresalgen. Bot. C'entrallil. 14: 1-1:.

- 1907. Weitere Be.itrige zur Kemntnis der Floridenenkeimlinge. Bot. (antralb. 21 : 148-15.

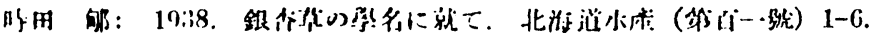

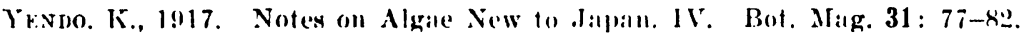

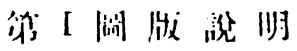

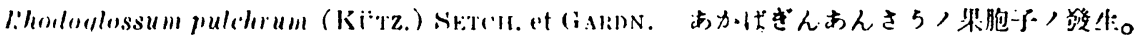

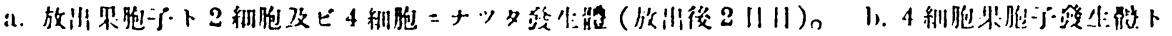

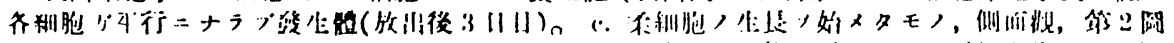

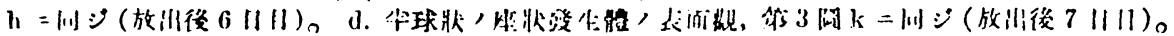

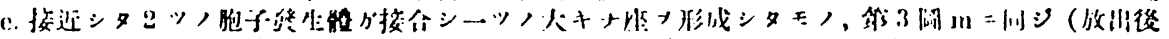

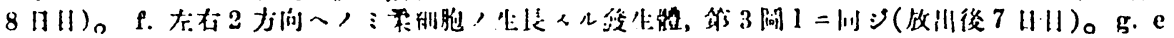

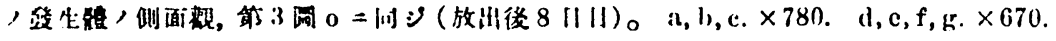

